\title{
Penerapan Model Pembelajaran Make a Match untuk Meningkatkan Hasil Belajar PAI dan Budi Pekerti Peserta Didik Kelas V SDN 176/X Majelis Hidayah Tahun pada Semester Ganjil Ajaran 2021/2022
}

\author{
Khodijah \\ SDN 176/X Majelis Hidayah \\ Jl. Siswa, Dusun II Desa, Majelis Hidayah, Jambi, Indonesia \\ marwatan@gmail.com
}

\begin{abstract}
This research is motivated by the learning outcomes of students towards PAI learning are still low and an effort is needed to improve it. The purpose of this study was to obtain information and discuss the application of the make a match learning model to improve PAI (Islamic Education) and character learning outcomes for fifth grade students of SDN 176/X Majelis Hidayah for the academic year 2021/2022. This type of research is classroom action research which consists of two cycles with each cycle consisting of four stages, namely planning, implementation, observation, and reflection. This research was carried out at SDN 176/X Majelis Hidayah in the odd semester of the academic year 2021/2022 with the research subjects being class V students at SDN 176/X Majelis Hidayah, totaling 17 students. Data collection techniques using tests, field notes, interviews, and documentation. Data were analyzed using percentages and data reduction. The results showed that through the cooperative learning model the make a match type could improve the understanding of PAI and Budi Pekerti learning of students in class V SDN 176/X Majelis Hidayah by giving rewards.
\end{abstract}

Keywords: Learning Outcomes, Islamic Education, Make a Match

\begin{abstract}
Abstrak
Penelitian ini dilatarbelakangi oleh hasil belajar peserta didik terhadap pembelajarn PAI masih rendah dan perlu adanya sebuah upaya untuk meningkatkanya. Tujuan dari penelitian ini adalah untuk mendapatkan informasi dan membahas tentang penerapan model pembelajaran make a match untuk meningkatkan hasil belajar PAI dan Budi Pekerti peserta didik kelas V SDN 176/X Majelis Hidayah tahun ajaran 2021/2022. Jenis penelitian ini adalah penelitian tindakan kelas yang terdiri dari dua siklus dengan masing-masing siklus terdiri dari empat tahapan yaitu perencanaan, pelaksanaan, observasi dan refleksi. Penelitian ini dilaksanakan di V SDN 176/X Majelis Hidayah pada semester ganjil tahun ajaran 2021/2022 dengan subjek penelitian peserta didik kelas V SDN 176/X Majelis Hidayah yang berjumlah sebanyak 17 orang Peserta didik. Teknik pengumpulan data menggunakan tes, catatan lapangan, wawancara dan dokumentasi. Data dianalisis menggunakan persentase dan reduksi data. Hasil penelitian menunjukkan bahwa melalui model pembelajaran kooperatif tipe make a match dapat meningkatkan pemahaman belajar PAI dan Budi Pekerti peserta didik di kelas V SDN 176/X Majelis Hidayah dengan tindakan pemberian reward.
\end{abstract}

Kata kunci: Hasil Belajar, Pendidikan Agama Islam, Make A Match

Copyright (c) 2022 Khodijah

Corresponding author: Khodijah

Email Address: Khodijah@ gmail.com (Jl. Maju Jaya, Tanjung Solok, Jambi)

Received 10 January 2022, Accepted 20 January 2022, Published 28 January 2022

\section{PENDAHULUAN}

Pendidikan merupakan salah satu komponen penting dalam meningkatkan kualitas sumber daya manusia. Pendidikan tidak hanya mencakup pengembangan intelektualtas saja, akan tetapi ditekankan pada proses pembinaan kepribadian anak didik dari usaha sadar dan terencana untuk mewujudkan suasan belajar dan proses pembelajaran agar peserta didik secara aktif mengembangkan potensi dirinya untuk menjadi pendidik yang aktif. Didalam keseluruhan proses pendidikan pada suatu lembaga pendidikan, kegiatan belajar mengajar merupakan kegiatan yang paling utama. Guru sangat 
memegang peranan yang sangat penting dalam mengajar (mendidik karena berhasil atau tidaknya suatu tujuan pengajaran ialah tergantung bagaimana guru tersebut dapat mengajarkan dengan baik dan dapat dipahami oleh peserta didik.

Pembelajaran merupakan perpaduan yang harmonis, antara kegiatan pengajaran yang dilakukan guru dan kegiatan belajar yang dilakukan oleh peserta didik. Dalam kegiatan pembelajaran tersebut, terjadi interaksi antara peserta didik dengan peserta didik, interaksi antara guru dengan peserta didik, maupun antara peserta didik dengan sumber belajar. Pembelajaran akan tercapai keberhasilannya apabila seorang guru merancang dan melaksanakan proses pembelajaran yang tepat, dengan pembelajaran yang terprogram maka akan tercipta suasana belajar yang menyenangkan, peserta didik tidak cepat jenuh dan bosan, sehingga peserta didik dapat secara aktif mengembangkan potensi dirinya.

Dalam Permendiknas Nomor 41 Tahun 2007 tentang standar proses juga diamanatkan bahwa dalam kegiatan inti pembelajaran harus dilakukan secara interaktif, inspiratif, menyenangkan, menantang, memotivasi peserta didik untuk berpartisipasi aktif, serta memberikan ruang yang cukup bagi prakarsa, kreatifitas dan kemandirian sesuai dengan bakat, minat dan perkembangan fisik dan psikologis peserta didik (Jauhar 2011: 1). Sebuah pembelajaran memerlukan teknik, metode dan pendekatan tertentu sesuai dengan karakteristik tujuan, peserta didik, materi dan sumber daya.

Berdasarkan pengamatan penulis ternyata masih banyak dijumpai permasalahan dalam proses pembelajaran, guru masih berperan dominan, minat dan respon peserta didik dalam mengikuti pelajaran masih sangat kurang. Hal ini terlihat dari kecenderungan peserta didik yang lebih banyak diam tanpa memperhatikan dan bila diberi pertanyaan masih kesulitan untuk menjawab. Hal tersebut juga terjadi pada peserta didik kelas V SDN 176/X Majelis Hidayah untuk mata pelajaran pendidikan agama islam (PAI) dari jumlah peserta didik 17 orang pada kelas V pada tahun ajaran 2021/2022 masih kurang dari 50\% nilai dibawah kriteria ketuntasan minimal (KKM). Untuk mengatasi permasalahan tersebut penulis melakukan penelitian untuk meningkatkan prestasi mata pelajaran pendidikan agama islam (PAI) pada kelas V dengan model pembelajaran Make a Match.

Dengan kajian tersebut, peneliti menerapkan pendekatan dengan model pembelajaran make $a$ match yang muncul dari konsep bahwa peserta didik akan lebih mudah menemukan dan memahami konsep yang sulit jika mereka saling berdiskusi dengan temannya. Peserta didik secara rutin bekerja dalam kelompok untuk saling membantu memecahkan masalah-masalah yang kompleks. Berdasarkan latar belakang yang telah dikemukakan, maka peneliti tertarik untuk melakukan penelitian dengan tujuan untuk mendapatkan informasi dan membahas tentang penerapan model pembelajaran make a match untuk meningkatkan hasil belajar PAI dan Budi Pekerti peserta didik kelas V SDN 176/X Majelis Hidayah semester ganjil tahun ajaran 2021/2022.

Belajar dalam pengertian luas dapat diartikan sebagai kegiatan psikofisik menuju ke perkembangan pribadi seutuhnya. Kemudian dalam arti sempit, belajar dimaksudkan sebagai usaha penguasaan meteri ilmu pengetahuan yang merupakan sebagian kegiatan menuju terbentuknya 
kepribadian seutuhnya (Sardiman, 2011: 22). Pada saat orang belajar maka responnya menjadi lebih baik dan sebaliknya bila tidak belajar responnya menjadi menurun sedangkan menurut Gagne belajar adalah seperangkat proses kognitif yang mengubah sifat stimulasi lingkungan, melewati pengolahan informasi, menjadi kapasitas baru (Dimyati, 2002: 10), sedangkan menurut kamus umum bahasa Indonesia belajar dapat diartikan berusaha (berlatih dan sebagainya) supaya mendapat suatu kepandaian (Purwadarminta, 2010).

Berdasarkan beberapa pendapat di atas dapat disimpulkan bahwa aktiftas belajar merupakan segala kegiatan yang dilakukan peserta didik baik secara fisik, mental, intelektual dan emosional dan berupa perpaduan antara aspek kognitif, afektif dan psikomotor dalam proses pembelajara secara maksimal. Belajar adalah segala usaha yang diberikan oleh guru agar mendapat dan mampu menguasai apa yang telah diterimanya dalam hal ini adalah pelajaran Pendidikan Agama Islam.

Hasil belajar merupakan perubahan yang diperoleh peserta didik setelah mengalami aktivitas belajar. Perubahan yang diperoleh tersebut tergantung pada apa yang dipelajari oleh peserta didik. Sudjana (2009:22) menyatakan bahwa hasil belajar adalah kemampuan-kemampuan yang dimiliki peserta didik setelah ia menerima pengalaman belajarnya. Hasil belajar merupakan suatu bukti bahwa seseorang telah belajar, yang dilihat dari perubahan tingkah laku pada orang tersebut dari tidak tahu menjadi tahu dan tidak mengerti menjadi mengerti (Hamalik 2014:30). Hasil belajar merupakan perubahan tingkah laku yang terjadi pada seseorang yang menerima pembelajaran, dari kondisi tidak tahu dan tidak mengerti akan sesuatu, karena ia belajar sehingga menghasilkan pengetahuan dan mengerti tentang hal yang ia pelajari.

Hasil belajar diterima oleh peserta didik apabila memberi kepuasan pada kebutuhannya dan berguna serta bermakna baginya. (Hamalik, Oemar. 2004:31). Menurut Suprijono (2012:5) "Hasil belajar adalah pola-pola perbuatan, nilai-nilai, pengertian-pengertian, sikap-sikap, apresiasi dan keterampilan". Berdasarkan pernyataan tersebut maka dapat ditarik kesimpulan bahwa hasil belajar merupakan perubahan perilaku secara menyeluruh (komprehensif) baik dari segi kognitif (pengetahuan), afektif (sikap), dan psikomotorik (keterampilan) pada pengembangan aspek potensi kemanusiaan.

Menurut Susanto (2015:5) mengatakan bahwa hasil belajar peserta didik adalah kemampuan yang diperoleh anak setelah melalui kegiatan belajar. Karena belajar itu sendiri merupakan suatu proses dari seseorang yang berusaha untuk memperoleh suatu bentuk perubahan perilaku yang relatif menetap. Dalam kegiatan pembelajaran atau kegiatan intruksional, biasanya guru menetapkan tujuan belajar. Anak yang berhasil dalam belajar adalah yang berhasil mencapai tujuan-tujuan pembelajaran atau tujuan intruksional. Menurut Nawawi dalam K. Brahim pada 2007:39 (dalam Susanto 2015:5) mengatakan bahwa hasil belajar dapat diartikan sebagai tingkat keberhasilan peserta didik dalam mempelajari materi pelajaran di sekolah yang dinyatakan dalam skor yang diperoleh dari hasil tes mengenal sejumlah materi pelajaran tertentu. 
Faktor-faktor yang mempengaruhi peserta didik dalam belajar juga mempengaruhi hasil belajar peserta didik. Berikut dijelaskan faktor-faktor yang mempengaruhi belajar, menurut Slameto (2003:54-60) faktor-faktor yang mempengaruhi belajar adalah faktor intern dan faktor ekstern. Faktor interen adalah faktor yang ada di dalam individu yang sedang belajar, sedangkan faktor ekstern adalah faktor yang ada di luar individu.

Berdasarkan pendapat para ahli tentang hasil belajar dan faktor-faktor yang mempengaruhi peserta didik dalam belajar maka penelitian ini mengacu pada teori Nawawi dalam K. Brahim pada 2007:39 (dalam Susanto 2015:5) yang mengatakan bahwa hasil belajar dapat diartikan sebagai tingkat keberhasilan peserta didik dalam mempelajari materi pelajaran di sekolah yang dinyatakan dalam skor yang diperoleh dari hasil tes mengenal sejumlah materi pelajaran tertentu.

Pembelajaran merupakan aspek kegiatan manusia yang kompleks, yang tidak sepenuhnya dapat dijelaskan. Pendidikan Agama Islam adalah upaya sadar dan terencana dalam menyiapkan peserta didik untuk mengenal, memahami, menghayati, hingga mengimani, ajaran agama Islam, dibarengi dengan tuntunan untuk menghormati penganut agama lain dalam hubungannya dengan kerukunan antar umat beragama hingga terwujud kesatuan dan persatuan bangsa (Kurikulum PAI, 2002:3). Adapun fungsi dari Pendidikan Agama Islam (PAI) itu diantaranya Pengembangan, yaitu meningkatkan keimanan dan ketakwaan peserta didik kepada Allah SWT yang telah ditanamkan dalam lingkungan keluarga. Penanaman nilai sebagai pedoman hidup di dunia dan di akhirat. Penyesuaian mental, yaitu untuk menyesuaikan diri dengan lingkungannya, baik lingkungan fisik maupun lingkungan sosial dan dapat mengubah lingkungannya sesuai dengan ajaran agama Islam. Penyaluran, yaitu untuk menyalurkan anak-anak yang memiliki bakat khusus di bidang Agama Islam agar bakat tersebut dapat berkembang secara optimal sehingga dapat dimanfaatkan untuk dirinya sendiri dan bagi orang lain. (Abdul Majid, 2004: 134).

Pendidikan Agama Islam (PAI) sendiri yaitu adalah usaha berupa bimbingan dan asuhan terhadap anak didik agar kelak setelah selesai pendidikannya dapat memahami dan mengamalkan ajaran agama Islam serta menjadikannya sebagai pendangan hidup (way of life). Selain itu, Pendidikan agama Islam juga merupakan pendidikan melalui ajaran-ajaran agama Islam, yaitu berupa bimbingan dan asuhan terhadap anak didik agar nantinya setelah selesai dari pendidikan ia dapat memahami, menghayati dan mengamalkan ajaran-ajaran agama Islam yang telah diyakininya secara menyeluruh, serta menjadikan ajaran agama Islam itu sebagai suatu pandangan hidupnya demi keselamatan hidup di dunia maupun di akhirat kelak.

Model merupakan interpretasi terhadap hasil observasi dan pengukuran yang diperoleh dari beberapa sistem. Model pembelajaran merupakan praktik pembelajaran hasil penurunan teori psikologi pendidikan dan teori belajar yang dirancang berdasarkan analisis terhadap implementasi kurikulum dan implikasinya pada tingkat operasional di kelas. Menurut Mills (Agus Suprijono, 2012:45), model adalah bentuk representasi akurat sebagai proses aktual yang memungkinkan seseorang atau sekelompok orang mencoba bertindak berdasarkan model itu. Menurut Joyce (Hamzah 
B. Uno, 2011:51) bahwa setiap model mengarahkan kita dalam merancang pembelajaran untuk membantu peserta didik dalam mencapai tujuan pembelajaran.

Menurut Arends (Agus Suprijono, 2012:46), model pemabelajaran mengacu pada pendekatan yang digunakan, termasuk di dalamnya tujuan-tujuan pembelajaran tahap-tahap dalam kegiatan pembelajaran, lingkungan belajar, dan pengelolaan kelas. Model pembelajaran adalah kerangka konseptual yang menggambarkan procedur sistematis dalam mengorganisasikan pengalaman belajar untuk mencapai tujuan belajar. Fungsi model pemebelajaran adalah sebagai pedoman bagi perancang pengajaran dan para guru dalam melaksanakan pembelajaran. Arends (1997) dikutip dari Hamzah B. uno (2011: 53) model pengajaran mengarah pada suatu pendekatan pembelajaran termasuk tujuannya, sintaksnya, lingkungannya, dan sistem pengelolaannya.

Berdasarkan uraian di atas, model pembelajaran adalah kerangka konseptual yang melukiskan prosedur sistematik dalam mengorganisasikan pengalaman belajar untuk mencapai tujuan belajar tertentu dan berfungsi sebagai pedoman bagi perancang pembelajaran dan para guru dalam merancang dan melaksanakan pembelajaran. Menurut Sumaatmadja (2001:104) model pembelajaran geografi terdapat tiga jenis model yaitu model pembelajaran disiplin mental, model pembelajaran kognitif, model pembelajaran sintetik.

Model pembelajaran make a match merupakan salah satu jenis dari model pembelajaran kooperatif, yakni bentuk pembelajaran dengan cara peserta didik belajar dan bekerja dalam kelompok-kelompok kecil secara kolaboratif yang anggotanya terdiri dari empat sampai enam orang dengan struktur kelompok yang bersifat heterogen. Menurut Rusman (2011: 223-233) Model Make A Match (membuat pasangan) merupakan salah satu jenis dari metode dalam pembelajaran kooperatif. Metode ini dikembangkan oleh Lorna Curran (1994). Salah satu cara keunggulan teknik ini adalah peserta didik mencari pasangan sambil belajar mengenai suatu konsep atau topik, dalam suasana yang menyenangkan.

Model make a match atau mencari pasangan merupakan salah satu alternatif yang dapat diterapkan kepada peserta didik. Penerapan metode ini dimulai dari teknik yaitu peserta didik disuruh mencari pasangan kartu yang merupakan jawaban/soal sebelum batas waktunya, peserta didik yang dapat mencocokkan kartunya diberi poin. Teknik metode pembelajaran make a match atau mencari pasangan dikembangkan oleh Lorna Curran. Salah satu keunggulan tehnik ini adalah peserta didik mencari pasangan sambil belajar mengenai suatu konsep atau topik dalam suasana yang menyenangkan.

Anita Lie (2008: 56) menyatakan bahwa model pembelajaran tipe make a match atau bertukar pasangan merupakan teknik belajar yang memberi kesempatan peserta didik untuk bekerja sama dengan orang lain. Teknik ini bisa digunakan dalam semua mata pelajaran dan untuk semua tingkatan usia anak didik. 
Berdasarkan pendapat di atas, dapat disimpulkan bahwa model pembelajaran kooperatif tipe Make A Match adalah suatu teknik pembelajaran Make A Match adalah teknik mencari pasangan sambil belajar mengenai suatu konsep atau topik dalam semua mata pelajaran dan tingkatan kelas.

Model pembelajaran Make a Match adalah sistem pembelajaran yang mengutamakan penanaman kemampuan sosial terutama kemampuan bekerja sama, kemampuan berinteraksi disamping kemampuan berpikir cepat melalui permainan mencari pasangan dengan dibantu kartu (Wahab, 2007: 59). Model make a match atau mencari pasangan merupakan salah satu alternatif yang dapat diterapkan kepada peserta didik. Penerapan metode ini dimulai dari teknik yaitu peserta didik disuruh mencari pasangan kartu yang merupakan jawaban/soal sebelum batas waktunya, peserta didik yang dapat mencocokkan kartunya diberi poin. Teknik metode pembelajaran make a match atau mencari pasangan dikembangkan oleh Lorna Curran (1994). Salah satu keunggulan tehnik ini adalah peserta didik mencari pasangan sambil belajar mengenai suatu konsep atau topik dalam suasana yang menyenangkan. Suyatno (2009 : 72) mengungkapkan bahwa model Make a Match adalah model pembelajaran dimana guru menyiapkan kartu yang berisi soal atau permasalahan dan menyiapkan kartu jawaban kemudian peserta didik mencari pasangan kartunya. Setiap model pembelajaran memiliki kelebihan dan kelemahan dibandingkan dengan model pembelajaran yang lainnya.

\section{METODE}

\section{Setting Penelitian}

Jenis penelitian ini adalah penelitian tindakan kelas yang terdiri dari dua siklus dengan masing-masing siklus terdiri dari empat tahapan yaitu perencanaan, pelaksanaan, observasi dan refleksi. Penelitian ini dilaksanakan di V SDN 176/X Majelis Hidayah pada semester ganjil tahun ajaran 2021/2022 dengan subjek penelitian peserta didik kelas V SDN 176/X Majelis Hidayah yang berjumlah sebanyak 17 orang Peserta didik. Teknik pengumpulan data menggunakan tes, catatan lapangan, wawancara dan dokumentasi. Data dianalisis menggunakan persentase dan reduksi data.

\section{HASIL DAN DISKUSI}

\section{Siklus I}

a. Perencanaan

Dalam perencanaan peneliti juga menyusun lembar pengamatan RPP, lembar pengamatan aktivitas guru dan aktivitas peserta didik yang akan diberikan kepada observer (guru kelas), kemudian lembar penilaian hasil belajar peserta didik yang terdiri dari ranah kognitif, afektif, dan psikomotor peserta didik serta LKS. Kemudian peneliti mendiskusikan dengan guru kelas tentang tata cara pengumpulan data dalam pelaksanaan observasi saat kegiatan dilakukan, agar tidak terjadi penyimpangan dalam pengambilan data. soal tes formatif 1 , dan alat-alat pengajaran yang mendukung. 


\section{b. Pelaksanaan}

Pertemuan pertama pada Rabu tanggal 17 September 2021 pada jam 08.00 WIB membahas materi tentang mengenal Rasul-rasul Allah dengan kompetensi dasar yaitu menyebutkan nama-nama Rasul Allah SWT. Tujuan pembelajaran pada pertemuan pertama ini adalah; 1) peserta didik dapat memahami pengertian beriman kepada Rasul-rasul Allah SWT, 2) Peserta didik dapat menyebutkan nama-nama Rasul Allah SWT. Pertemuan pertama terdiir dari tiga kegiatan yaitu pendahuluan, inti dan penutup.

Pendahuluan, peneliti dan kolaborator Memeriksa kehadiran peserta didik, kebersihan dan kerapian kelas, kemudian menyampaikan kopetensi dasar yang harus dikuasai peserta didik, dan apersepsi. Peneliti memberikan cerita singkat dan menarik yang berkaitan dengan materi kemudian mengajukan beberapa pertanyaan yang berhubungan dengan Rasul-rasul Allah SWT. Kegiatan Inti, dalam kegiatan inti menjelaskan materi pembelajaran secara umum, Menyampaikan metode pembelajaran yang akan diterapkan. Membagi peserta didik menjadi kelompok, dan satu kelompok 56 anggota. Menentukan topik pembelajaran yang akan didiskusikan, Guru menyiapkan beberapa kartu yang berisi konsep atau topik yang cocok untuk sesi review, satu bagian soal dan satu bagian yang lain kartu jawaban, Setiap peserta didik mendapat sebuah kartu yang bertulis soal atau jawaban. Tiap peserta didik memikirkan jawaban atau soal dari kartu yang dipegang, Setiap peserta didik mencari pasangan kartu yang cocok dengan kartunya. Kegiatan Penutup, guru dan peserta didik membuat kesimpulan tentang materi pembelajaran. Guru mengadakan tanya jawab dengan peserta didik seputar pemahaman peserta didik tentang defenisi beriman kepada Rasul-rasul Allah SWT dan nama-namanya yang telah dipelajari.

Pertemuan kedua dilaksanakan pada hari Selasa tanggal 28 September 2021 pada jam 08.00 WIB dengan materi membahas tentang mengenal Rasul-rasul Allah dengan kompetensi dasar menyebutkan nama-nama Rasul Ulul Azmi dari para Rasul. Tujuan pembelajaran pada pertemuan kedua ini peserta didik diharapkan dapat memahami pengertian Rasul Ulul Azmi dan dapat menyebutkan nama-nama Rasul Ulul Azmi dari para Rasul. Pertemuan kedua ini terdiri dari tiga kegiatan yaitu pendahuluan, inti dan penutup.

Pada kegiatan pendahuluan, guru mengadakan apersepsi dengan melakukan tanya jawab kepada para peserta didik yang berguna untuk mengetahui daya serap peserta didik terhadap materi pelajaran yang telah lalu. Setelah itu guru mulai menjelaskan sepintas materi yang akan dipelajari sesuai dengan rencana pelaksanaan pembelajaran yang telah dibuat sebelumnya. Pembentukan kelompok dipilih secara acak. Guru menjelaskan pokok-pokok kegiatan peserta didik mulai dari mengamati, mengajukan pertanyaan, mengumpulkan informasi, sampai pada menampilkan hasil kerja kelompok. Guru kemudian menjelaskan kegiatan pembelajaran. Peserta didik diberikan kesempatan untuk membuat 2 pertanyaan sehubungan dengan hal-hal yang ingin diketahui. Setelah 8 pertanyaan terkumpul, masing-masing kelompok di persilahkan menjawab pertanyaan, tanpa membaca buku sumber. Sebelum pembelajaran ditutup, guru mengadakankan kuis dengan memberikan 2 soal yang 
harus dijawab peserta didik dalam waktu 5 menit saja dan dikumpulkan. Guru memberitahukan materi berikutnya. Peserta didik diberi tugas mengerjakan lembar tugas pribadi yang dibagikan guru. Guru menghimbau peserta didik agar mempersiapkan diri menghadapi Ulangan Harian Siklus I. Guru memimpin do'a dan memberikan salam penutup sebelum meninggalkan kelas.

c. Observasi

Ketuntasan hasil belajar peserta didik dalam menganalisis hasil belajar melalui Ulangan Harian I dengan menggunakan model pembelajaran make a match dapat dilihat pada tabel berikut adalah:

Tabel 1. Rekapitulasi Hasil Tes Formatif Siklus I

\begin{tabular}{|c|l|l|}
\hline No & Keterangan & Nilai \\
\hline 1 & Jumlah & 1155 \\
\hline 2 & Rata-Rata & 67.94 \\
\hline 3 & Nilai Tertinggi & 75 \\
\hline 4 & Nilai Terendah & 61 \\
\hline 5 & Jumlah Peserta Didik yang Tuntas & 10 Orang \\
\hline 6 & Persentase Ketuntasan & $59 \%$ \\
\hline
\end{tabular}

Berdasarkan tabel di atas, diketahui bahwa pada siklus I jumlah peserta didik yang tuntas 10 orang $(59 \% \%)$ dan peserta didik yang tidak tuntas 7 orang $(41 \%)$. Dengan demikian dapat dijelaskan bahwa jumlah peserta didik yang tuntas dibawah rata-rata pencapaian KKM Klasikal yang diinginkan. Hal ini disebabkan karena peserta didik masih belum begitu paham dengan metode yang diberikan oleh guru. Masih banyak peserta didik yang yang belum terlalu paham engan metode baru yang diberikan guru, disebabakan metode tersebut baru bagi peserta didik. Untuk itu perlu adanya perbaikan - perbaikan pada siklus berikutnya.

d. Refleksi

Peneliti dan kolaborator melakukan refleksi pada hari Kamis tanggal 30 September 2021 dibantu oleh seorang observer yang bernama Hamidah, S.Pd. yang dilaksanakan di ruang majelis guru SDN 176/X Majelis Hidayah. Berdasarkan hasil refleksi pada siklus I masih terdapat beberapa kelemahan selama proses pembelajaran, yaitu: 1) Pada aspek pengorganisasian materi ajar, cakupan materi ajar belum luas dan belum sesuai dengan alokasi waktu yang direncanakan, 2) Pada kelengkapan instrumen, soal belum disertai pedoman penskoran yang lengkap, 3) Pada pelaksanaan guru belum menuliskan topik yang akan dipelajari di papan tulis dan tujuan pembelajaran sulit dimengerti, 4) Dalam kelompok peserta didik masih ada yang dominan aktif dalam kelompok, 5) Peserta didik masih belum berani untuk mengemukakan pendapatnya selama diskusi, 6) Berdasarkan analisis data tersebut pada refleksi siklus I diatas perlu diadakan perbaikan pada siklus II. Alasan perlu perbaikan karena belum tercapainya target dan sasaran penelitian setiap indikator pembelajaran. Maka perbaikan yang akan dilaksanakan pada siklus II antara lain: 1) Guru lebih memotivasi peserta didik untuk aktif dalam mengajukan pertanyaan, menjawab pertanyaan, menyatakan pendapat dan mengemukakan ide serta menanggapi pendapat temannya, 2) Guru mengganti formasi kelompok, 
sehingga anggota tiap kelompok, terdapat peserta didik yang pandai, percaya diri, kurang pandai atau kurang percaya diri, 3) Memberikan reward bagi peserta didik yang berhasil.

\section{Siklus II}

a. Perencanaan

Dalam perencanaan peneliti juga menyusun lembar pengamatan RPP, lembar pengamatan aktivitas guru dan aktivitas peserta didik yang akan diberikan kepada observer (guru kelas), kemudian lembar penilaian hasil belajar peserta didik yang terdiri dari ranah kognitif, afektif, dan psikomotor peserta didik serta LKS .Kemudian peneliti mendiskusikan dengan guru kelas tentang tata cara pengumpulan data dalam pelaksanaan observasi saat kegiatan dilakukan, agar tidak terjadi penyimpangan dalam pengambilan data. soal tes formatif 1 , dan alat-alat pengajaran yang mendukung.

b. Pelaksanaan

Pertemuan pertama dilaksanakn pada hari Kamis tanggal 7 Oktober 2021 pada jam 08.00 WIB dengam nateri membahas tentnag mengenal kitab-kitan Allah SWT dan kompetensi dasar yaitu menyebutkan nama-nama kitab Allah SWT. Tujuan pembelajaran pada pertemuan pertama ini adalah peserta didik dapat menjelaskan pengertian beriman kepada kitab Allah SWT dan peserta didik dapat menyebutkan nama-nama kitab Alah SWT dengan benar. Pertemuan pertama siklus II terdiri dari tiga kegiatan yaitu pendahuluan, inti, dan penutup.

Guru dan kolaborator memasuki kelas dan duduk di tempat masing-masing. Guru mengucapkan salam pembuka, menyapa dan mengkondisikan peserta didik untuk mengikuti pembelajaran. Guru membuka pelajaran dengan mengajak peserta didik berdo'a terlebih dahulu. Setelah guru memberikan penguatan bahwa kegiatan ini nantinya akan menjadikan belajar lebih mudah dan menyenangkan bila mereka mau bekerja sama. Peserta didik dibagi menjadi 4 kelompok, dengan susunan keanggotaan yang dirancang oleh guru. Guru membagikan LKS dan menjelaskan cara kerjanya. Peserta didik diminta mengamati sebuah gambar yang ditampilkan di papan tulis, Kemudian guru meminta peserta didik berdiskusi tentang gambar tersebut dan diharuskan mengajukan sebuah masalah yang berkaitan. Guru membimbing peserta didik dalam menjalankan diskusinya. Pada kegiatan akhir guru merefleksi pembelajaran dengan Tanya jawab dengan peserta didik. Dan memberikan penguatan pada peserta didik serta membuat kesimpulan guru dna peserta didik tentang pembelajaran yan dipelajari.

Pertemuan kedua dilaksanakan Selasa tanggal 19 Oktober 2021 pada jam 08.00 WIB. Pada pertemuan kedua ini membahas tentang mengenal kitab-kitab Allah SWT dengan komptensi Dasar yaitu menyebutkan nama-nama Rasul yang telah menerima kitab-kitab Allah SWT. Tujuan pembelajaran pada pertemuan ini peserta didik dapat menyebutkan nama-nama rasul yang menerima kitab-kita Allah SWT dan dapat mengetahui usaha para rasul dalam menyampaikan ajaran dari kitabkitab Allah SWT. pertemuan ini terdiri dari tiga kegiatan yaitu pendahuluan, inti, dan penutup.

Pada kegiatan pendahuluan, guru meminta semua peserta didik memperhatikan kerapian diri 
dan kebersihan lingkungan. Pembelajaran dimulai dengan mengucapkan do'a. Guru menanyakan kehadiran peserta didik, ternyata semua peserta didik hadir dengan Peserta didik diminta membaca buku paket untuk mengumpulkan data-data. Kemudian peserta didik diminta mendiskusikan jawaban dari LKS yang dibagikan. Pada kegiatan inti guru menjelaskan topik, tujuan dan hasil belajar dengan materi pemeblejaran yaitu tentang nama-nama rasul yang menerima kitab-kitan Allah SWT. Guru membimbing peserta didik untuk dapat memunculkan pendapat tentang bahasan yang terkandung dalam materi tersebut. Dan peserta didik mendiskusikannya. Kemudian peserta didik dibagikan kartu dan mencocokkan kartunya dengan jawabannya yang berada pada temannya. Peserta didik sangat antusias ketika proses pembelajaran berlangsung. Bagi peserta didik yang telah mampu mencocokan kartunya maka mereka berdua menjelaskan materi yang terdapat pada kartu tersebut. Hingga semuanya menemukan pasangannya. Pada kegiatan penutup, guru dan peserta didik membuat kesimpulan tentang proses pembelajaran yang berlangsung. Dan mengumumkan melakukan evaluasi pembelajaran dengan kuis, yang dikerjakan secara individu.

c. Observasi

Pada akhir proses belajar mengajar peserta didik diberi tes formatif I dengan tujuan untuk mengetahui tingkat keberhasilan peserta didik dalam proses belajar mengajar yang telah dilakukan. Adapun data hasil penelitian pada siklus I adalah sebagai berikut:

Tabel 2. Rekapitulasi Hasil Tes Formatif Siklus II

\begin{tabular}{|c|l|l|}
\hline No & Keterangan & Nilai \\
\hline 1 & Jumlah & 1226 \\
\hline 2 & Rata-Rata & 72.12 \\
\hline 3 & Nilai Tertinggi & 80 \\
\hline 4 & Nilai Terendah & 65 \\
\hline 5 & Jumlah Peserta Didik yang Tuntas & 14 Orang \\
\hline 6 & Persentase Ketuntasan & $82 \%$ \\
\hline
\end{tabular}

Dari tabel di atas diperoleh nilai rata-rata hasil belajar peserta didik adalah 72.17 dan ketuntasan belajar pendidikan agama islam (PAI) mencapai $82 \%$ atau ada 14 peserta didik dari 19 Peserta Didik sudah tuntas belajar. Hasil ini menunjukkan bahwa pada siklus II ini ketuntasan belajar secara klasikal telah mengalami peningkatan lebih baik dari siklus I. Adanya peningkatan hasil belajar peserta didik ini karena setelah guru menginformasikan bahwa setiap akhir pelajaran akan selalu diadakan tes sehingga pada pertemuan berikutnya peserta didik lebih termotivasi untuk belajar. Selain itu peserta didik juga sudah mulai mengerti apa yang dimaksudkan dan dinginkan guru dengan menerapkan metode pembelajaran kooperatif tipe Make a Match.

d. Refleksi

Pada siklus II, refleksi yang dilakukan dengan observer pada hari Kamis tanggal 21 Oktober 2021 di ruangan rmajelis guru SDN 176/X Majelis Hidayah yang dibantu oleh seorang observer yang bernama Hamidah, S.Pd. Berdasarkan hasil diskusi ditemukan bahwa langkah pembelajaran telah 
dilaksanakan dengan lebih baik. Namun, ada sedikit kekurangan yakni pada pengorganisasian materi ajar belum sesuai dengan alokasi waktu. Menyiapkan kondisi untuk memulai pembelajaran. Pada langkah ini tidak ada upaya perbaikan yang perlu dilakukan karena semua hasil yang dinginkan sudah terlihat. Guru lebih memberi kesempatan pada kelompok lain untuk memberi saran dan tanggapan terhadap hasil kerja kelompok yang tampil, dan guru lebih menyempurnakan kesimpulan pembelajaran yang disampaikan peserta didik, agar peserta didik lebih mengerti dan tidak terjadi kesalahan konsep pada peserta didik. Dan pada siklus II target penelitian telah tercapai sehingga tidak dilanjutkan ke siklus III.

\section{Diskusi}

Dalam pembelajaran dengan model pembelajaran make a match ini, guru membimbing peserta didik berada disamping mereka yang membutuhkan bimbingan, membuat peserta didik merasa puas dan senang dan merasa diperhatikan sehingga peserta didik merasa bersemangat belajar. Perbandingan persentase pencapaian KKM pada siklus I dan siklus II adalah sebesar $59 \%$ dan $82 \%$. Dari peningkatan hasil belajar pendidkan agama islam (PAI) setiap siklus, dapat disimpulkan bahwa penerapan model pembelajarn make a match, dapat meningkatkan hasil belajar pendidikan agama islam (PAI) dan Budi Pekerti di kelas SDN 176/X Majelis Hidayah. Keberhasilan seorang peserta didik ditentukan oleh dirinya sendiri ketika mereka mendapatkan materi disekolah yang diajarkan oleh guru. Proses pembelajaran didalam kelas tidak terlepas dari dua komponen penting yaitu guru sebagai seorang pendidik dan peserta didik sebagai peserta didik.

Proses belajar merupakan suatu kegiatan dimana seseorang membuat atau menghasilkan suatu perubahan tingkah laku yang ada pada dirinya dalam pengetahuan, sikap, dan ketrampilan (Sadirman, 2004: 24). Salah satu metode pembelajaran dari kooperative learning dengan model make a macth (membuat pasangan) merupakan salah satu jenis dari metode dalam pembelajaran kooperatif. Metode ini dikembangkan oleh Lorna Curran (1994). Salah satu keunggulan teknik ini adalah peserta didik mencari pasangan sambil belajar mengenai suatu konsep atau topik, dalam suasana yang menyenangkan (Rusman, 2013: 223).

\section{KESIMPULAN}

Setelah melaksanakan penelitian tindakan kelas yang telah dilakukan berdasakan hasil observasi dan hasil refleksi yang telah dilakukan selama penelitian, maka dapat diambil kesimpulan bahwa melalui model pembelajaran kooperatif tipe make a match dapat meningkatkan hasil belajar pendidikan agama islam (PAI) dan Budi Pekerti peserta didik kelas V SDN 176/X Majelis Hidayah degan tindakan pemberian reward. Hal ini dapat dilihat dari ketuntasan belajar peserta didik dari siklus I (59\%) meningkat pada siklus II (82\%).

Berdasarkan kesimpulan dan implementasi diatas, saran yang disajikan adalah : 1) Pembelajaran pendidikan agama islam (PAI) seharusnya dilakukan secara bervariasi, sehingga peserta didik dalam proses pembelajaran tidak merasa bosan, 2) Proses pembelajaran ini sebaiknya direkam 
dalam sebuah vidio sehingga seluruh aktivitas baik guru, peserta didik dalam proses pelaksanaan bisa terekam dengan baik sebagai bukti fisik serta sebagai acuan untuk mereview kembali proses yang sudah dilaksanakan serta memudahkan dalam mencari kekurangan dalam proses pembelajaran, 3) Sebaiknya dalam melakukan tes terhadap peserta didik dilaksanakan tes uji lisan dalam belajar supaya kemampuan peserta didik dalam belajar sejarah kebudayaan islam setiap individu peserta didik benar-benar diketahui.

\section{UCAPAN TERIMA KASIH}

Ucapan terima kasih sangat layak disampaikan untuk semua pihak yang telah membantu dalam pengerjaan artikel ini. Baik teman, dosen, kakak, dan yang lainnya. Artikel ini dapat dibuat karena adanya bantuan mereka. Semoga artikel ini dapat bermanfaaat untuk banyak pihak.

\section{REFERENSI}

A.M, Sardiman. (2004). Interaksi dan motivasi belajar mengajar. Jakarta: PT Raja. Grafindo Persada. A.M. Sardiman. (2011). Interaksi dan Motivasi Belajar Mengajar. Jakarta: PT Rajagrafindo.

Ahmad Susanto. (2015). Teori Belajar \& Pembelajaran di Sekolah Dasar. Jakarta: Kencana Penamedia Group.

Rusman. (2013). Metode-Metode Pembelajaran: Mengembangkan. Profesionalisme Guru. Jakarta: PT RajaGrafindo Persada.

Djamarah, Syaiful Bahri. (2012). Psikologi Belajar. Jakarta: Rineka Cipta

Abdul, Aziz Wahab. (2007). Metode dan Model-Model Mengajar. Bandung: Alfabeta.

Anita Lie. (2008). Cooperative Learning: Mempraktikkan Cooperative Learning di Ruang-Ruang Kelas. Jakarta: Grasindo.

Dimyati dan Mudjiono. (2002). Belajar dan Pembelajaran. Jakarta: Rineka Cipta

Hamalik, Oemar. (2004). Proses Belajar Mengajar. Bumi Aksara. Jakarta

Hamalik, Oemar. (2014). Kurikulum dan Pembelajaran. Jakarta: Bumi Aksara.

Hamzah B. Uno. (2011). Teori Motivasi dan Pengukurannya: Analisis di Bidang Pendidikan. Jakarta: Bumi aksara.

Abdul Majid, dan Dian Andayani. (2004). Pendidikan Agama Islam Berbasis. Kompetensi. Bandung: PT. Remaja Rosda Karya

Jauhar, Mohammad. (2011). Implementasi PAIKEM dari Behavioristik sampai. Konstruktivistik. Jakarta: Prestasi Pustakaraya

Agus, Suprijono. (2012). Cooperative Learning: Teori dan Aplikasi Paikem. Yogyakrta: Pustaka Pelajar

Sudjana, Nana. (2009). Dasar-dasar Proses Belajar Mengajar. Bandung: Sinar. Baru Algensindo. Slameto. (2003). Belajar dan Faktor-faktor yang mempengaruhinya. Jakarta: Rineka Cipta Sumaatmadja. (2001). Metodologi Pengajaran Geografi. Jakarta: PT Bumi. 
Imas Kurniasih \& Berlin Sani. (2015). Ragam Pengembangan Model Pembelajaran untuk Peningkatan Profesionalitas Guru. Jogjakarta: Kata Pena.

Permendiknas Nomor 41 Tahun 2007

Rusman. (2011). Model-Model Pembelajaran: Mengembangkan Profesionalisme Guru. Jakarta: Rajawali Pers, Jakarta

Suyadi. (2013). Strategi Pembelajaran Pendidikan Karakter. Bandung: Remaja Rosdakarya. Suyatno. (2009). Menjelajah Pembelajaran Inovatif. Sidoarjo: Masmedia Buana Pusaka Undang-Undang Sistem Pendidikan Nasional No. 20 Bab I pasal I ayat I Tahun 2003 